\title{
Processes of Removing Zinc from Water using Zero-Valent Iron
}

\author{
Tomasz Suponik • Antoni Winiarski • Jacek Szade
}

Received: 20 June 2015 / Accepted: 8 September 2015 / Published online: 5 October 2015

(C) The Author(s) 2015. This article is published with open access at Springerlink.com

\begin{abstract}
Zero-valent iron has received considerable attention for its potential application in the removal of heavy metals from water. This paper considers the possibility of removal of zinc ions from water by causing precipitates to form on the surface of iron. The chemical states and the atomic concentrations of solids which have formed on the surface of zero-valent iron as well as the type of the deposited polycrystalline substances have been analyzed with the use of X-ray photoelectron spectroscopy (XPS) and X-ray diffraction (XRD), respectively. The BET surface area, the $\mathrm{pH}$ at point of zero charge $\left(\mathrm{pH}_{\mathrm{PZC}}\right)$, the ORP of the solutions, and the $\mathrm{pH}$ and chemical concentrations in the solutions have also been measured. Furthermore, the paper also considers the possibility of release of zinc from the precipitates to demineralised water in changing physicochemical and chemical conditions. In a wide range of $\mathrm{pH}$ values, $\mathrm{Zn}_{x} \mathrm{Fe}_{3-x} \mathrm{O}_{4}$ (where $x \leq 1$ ) was the main compound resulting from the removal of zinc in ionic form from water. In neutral and alkaline conditions, the adsorption occurred as an additional process.
\end{abstract}

Keywords Zero-valent iron · Zinc · X-ray photoelectron spectroscopy $\cdot$ Diffraction $\cdot$ Surface charge

T. Suponik $(\bowtie)$

Silesian University of Technology, Akademicka 2,

44-100 Gliwice, Poland

e-mail: Tomasz.Suponik@polsl.pl

A. Winiarski $\cdot$ J. Szade

University of Silesia, Uniwersytecka 4, 40-007 Katowice, Poland

\section{Introduction}

Zinc is a metal which finds its application in multiple industries. The minerals most commonly exploited for the purposes of zinc production are sphalerite, smithsonite, and calamine. Zinc is essential for human metabolism, but may also pose certain risks. Free zinc ions in solutions are highly toxic to bacteria, plants, invertebrates, and even vertebrate fish (Ronald 1993).

Wastes resulting from the mining of non-ferrous metal ores and hard coal as well as from the manufacturing process of non-ferrous metals accumulated at industrial waste disposal sites contain zinc minerals and, as a result, may affect the quality of ground and surface waters in the southern provinces of Poland. Meanwhile, the Water Framework Directive (Directive 2000/60/EC of the European Parliament and of the Council) issued in October 2000 commits European Union members states to achieve a good qualitative and quantitative status of all water bodies by 2015 . Therefore, the problem associated with waste dumps in Silesia, Poland, and their impact on ground and surface waters must be solved as soon as possible. The $\mathrm{pH}$ of the groundwater under the waste disposal sites for wastes resulting from the mining of hard coal and non-ferrous metal ores and from the manufacture of non-ferrous metals is slightly acidic and rather neutral or alkaline, respectively.

Permeable reactive barrier technology with the use of zero-valent iron (ZVI) as a reactive material may be applied to remove free zinc ions from groundwater and thus to protect the surface waters. In this technology, the contaminants are removed from the aquifer during the 
flow of the groundwater through a permeable reactive barrier (PRB) filled with a reactive material. The application of zero-valent iron to remove zinc in cationic form from water has been investigated before (Morrison et al. 2002; Wilkin and McNeil 2003; Kishimoto et al. 2011; Rangsivek and Jekel 2005; Bruzzoniti and Fiore 2014). This research revealed the effectiveness of ZVI in the zinc removal process. The literature, however, includes conflicting reports regarding the mechanism of that process. For example, according to Kishimoto et al. (2011), the mechanism of zinc removal with the use of ZVI powder is as follows: ZVI firstly corrodes and oxidizes into ferric ions by means of dissolved oxygen. The ferric ions then precipitate as iron hydroxide onto the surface of the ZVI powder. Zinc ions adsorb on and/or coprecipitate with the iron hydroxide. The iron hydroxide is then finally oxidized and transformed into iron oxides. Meanwhile, Wilkin and McNeil (2003) and Oh et al. (2007) claim that the rapid removal of heavy metals using zero-valent iron in water contaminated by acid mine drainage proceeds due to the adsorption onto the surface of iron metal or onto iron corrosion products. In the research presented in a paper by Li and Zhang (2007), the predominant removal mechanism for metal ions with a standard potential very close to or more negative than that of iron is sorption/surface complex formation. At this point, it should be made clear that the type of process obviously depends on the chemical and physicochemical composition of the solution. In general, sorption as a removal mechanism is not preferred because soluble zinc $\mathrm{Zn}$ (II) remains in its more soluble oxidation state, and in case of a change in the physicochemical conditions, it may be released back to the environment.

In relation to the above, the matters that could raise interest in the view of ZVI application are the types of products formed on the surface of ZVI as a result of zinc removal from water characterized by low, neutral, and high $\mathrm{pH}$ values, the possibility of zinc release from the surface of ZVI to demineralised water upon a change in the physicochemical and chemical conditions, as well as the type of the dominant processes that result in the removal of $\mathrm{Zn}$ (II) from water. These issues have been discussed in the study.

According to Eh-pH diagrams of the Zn-O-H system presented by Takeno (2005), zinc in solutions exists mainly in its divalent ionic form up to the $\mathrm{pH}$ value of 8.5. Between the $\mathrm{pH}$ of 8.5 and ca. $11, \mathrm{Zn}(\mathrm{OH})_{2}$ and the cationic species such as $\mathrm{Zn}(\mathrm{OH})^{+}$become increasingly effective. In the $\mathrm{pH}$ ranges analyzed in the study, zinc ions were expected to occur in divalent form during the experiments.

\section{Materials and Method}

In order to remove cationic zinc from solutions at various $\mathrm{pH}$ values, zero-valent iron constituted the iron samples. The samples used in the batch tests were made of steel (in accordance with EN 10131:2006, "cold rolled uncoated low carbon and high yield strength steel flat products for cold forming"). The samples were square-shaped, made of cold-rolled steel sheet ( $0.5 \mathrm{~mm}$ thickness), and their dimensions were $5 \times 5 \mathrm{~mm}$. Just before their use, the samples were immersed in concentrated nitric acid for ca. $120 \mathrm{~s}$ and in demineralised water for ca. $120 \mathrm{~s}$, immediately after that they were used in the batch tests. The tests were conducted in a programmable MULTI BIO RS-24 BIOSAN rotator equipped with plastic tubes filled with zinc solution (so as to eliminate the headspace - a gaseous phase above the solutions; the volume of the solution amounted to $58 \mathrm{~cm}^{3}$ ) with the initial $\mathrm{pH}$ of 4.5, 7.0, and 9.5 and with iron samples - only one iron sample was introduced to each plastic tube. The $\mathrm{pH}$ levels of the solutions were adjusted by slow titration with ultra-pure sulphuric acid solution $(0.1 \mathrm{M})$ or with ultra-pure sodium hydroxide solution $(0.1 \mathrm{M})$. Zinc ion solutions were prepared by adding the desired amounts of metal salt $\left(\mathrm{ZnSO}_{4} \cdot 7 \mathrm{H}_{2} \mathrm{O}\right)$ into bottles and pouring distilled water. The concentration of zinc in the solutions at $\mathrm{pH}$ levels of 4.5, 7.0, and 9.5 amounted to 5.57, 7.06, and $6.12 \mathrm{mg} / \mathrm{dm}^{3}$, respectively. The intention of the authors was to exceed the allowable concentration of zinc by several times within the meaning of legal regulations provided in the Journal of Laws (2014, item 1800). This value in the discharged water is $2 \mathrm{mg} / \mathrm{dm}^{3}$.

Dissolved oxygen (DO) has a significant impact on the behavior of $\mathrm{Zn}$ in the groundwater. The concentration of DO in groundwater (in an unconfined aquifer) located in the vicinity of coal waste disposal sites in the south of Poland amounted to ca. $6 \mathrm{mg} / \mathrm{dm}^{3}$ (based on own measurements - the samples of water were taken by the authors using a WHG-168 STALTECHNIKA drilling rig. The aquifers were located at a depth of about $10 \mathrm{~m}$ below the surface of the ground). In order to reduce the concentration of oxygen in the samples of water and to adjust their condition to the condition of the contaminated aquifer, the solutions were heated before using them in the batch tests (to the temperature of 
$308 \mathrm{~K})$. This way, the initial concentration of DO amounted to ca. $6 \mathrm{mg} / \mathrm{dm}^{3}$. The ambient air temperature in the laboratory was ca. $295 \mathrm{~K}$.

After filling, the plastic tubes were sealed with corks and the first batch tests were carried out. Each sample had to undergo $5 \mathrm{~min}$ of orbital rotation in a programmable rotator (with a speed range of $20 \mathrm{rpm}$ ) after which a 6-s reciprocal motion (with a turning angle of $90^{\circ}$ ) with a vibration motion followed. This sequence of shaking was repeatedly reiterated. The sequence continued for $24 \mathrm{~h}$ (after this time, constant values were achieved). After shaking the samples, the solutions were passed through dense filters and assessed. The $\mathrm{pH}$, oxidation-reduction potential (ORP), DO, and conductivity were measured using Knick PORTAMESS meters. The quantitative analyses of chemicals in solutions were carried out for the following:

- $\mathrm{Zn}_{\text {total }}$, with the use of DR5000 Hach Lange UV-Vis Spectrophotometer-Zincon Method; method 8009 of Hach Co.; test results are measured at $620 \mathrm{~nm}$. The concentration of zinc in the solutions was measured in a spectrophotometer as a total value $\left(\mathrm{Zn}_{\text {total }}\right)$. Since there was no zinc speciation (at the beginning) in the solutions other than the $\mathrm{Zn}$ (II), the removal of the zinc in the second oxidation state has been assessed in the article.

- Fe(II) with the use of DR5000 Hach Lange UV-Vis Spectrophotometer-1, 10 Phenanthroline Method; method 8146 of Hach Co.; test results are measured at $510 \mathrm{~nm}$.

- $\mathrm{Fe}_{\text {total }}$ with the use of DR5000 Hach Lange UV-Vis Spectrophotometer-FerroVer Method; method 8008 of Hach Co.; test results measured at $510 \mathrm{~nm}$. The concentration of dissolved Fe(III) was calculated as a difference between $\mathrm{Fe}_{\text {total }}$ and $\mathrm{Fe}(\mathrm{II})$.

- $\mathrm{SO}_{4}{ }^{2-}$, DR5000 Hach Lange UV-Vis Spectrophotometer-SulfaVer 4 Method; method 8051 of Hach Co.; test results measured at $450 \mathrm{~nm}$.

The measurements were carried out twice. The results, shown in Table 1, were calculated as an arithmetic mean.

After shaking, all the iron samples were pulled out, washed with demineralised water, wiped gently with a paper towels and dried in an exsiccator. In order to identify the products formed on the surface of the samples and to determine their affinity with zinc in ionic form, the following tests were conducted on iron samples before and after the batch tests:
- Determination of crystalline substances present on the surface of iron samples before and after the batch tests. These measurements were carried out with the use of X-ray diffraction (XRD). For the analysis of solid objects, EMPYREAN X-ray Multipurpose Diffractometer by PANalytical was used. The diffractometer was equipped with PreFIX (pre-aligned, fast interchangeable X-ray) modules allowing for an effortless change in the optical path. The PDF4+ database was used for the identification of chemical compounds. Crystal lattice parameters were measured.

- Identification of elements and determination of atomic concentrations of solids located on the surface of iron samples formed before and after the batch tests. These measurements were carried out with the use of X-ray photoelectron spectroscopy (XPS). This method allowed for the identification of the elements (except for $\mathrm{H}$ and $\mathrm{He}$ ) and their chemical states as well as for the calculation of their atomic concentrations. Measurements were performed using a PHI 5700/660 Multipurpose Electron Spectrometer based on two separate test chambers joined by an UHV transfer system by Physical Electronics using a monochromatized $\mathrm{Al}_{\mathrm{K} \alpha}$ radiation $(\mathrm{h} v=1486.6 \mathrm{eV})$. The energy resolution of the spectrometer equipped with a hemispherical energy analyzer was approximately $0.3 \mathrm{eV}$. The anode was operated at $15 \mathrm{kV}$ and $225 \mathrm{~W}$. Survey and multiplex high-resolution spectra (HRES; multiplex) were measured in ultrahigh vacuum. High-resolution spectra were fitted using mixed Gaussian and Lorentzian functions and Shirley background with the application of MultiPak program. The range in survey mode was from -2 to $1400 \mathrm{eV}$. The measurement parameters for survey mode and HRES (highresolution mode) were respectively pass energy 187.85 and 23.50 , step 0.800 and $0.100 \mathrm{eV}$, and time per step 20 and $100 \mathrm{~ms}$. The sizes of the analyzed areas were $1.5 \times 2.5 \mathrm{~mm}$ (to identify the trends in case different $\mathrm{pH}$ values of the solutions were used) and the diameter was $0.8 \mathrm{~mm}$ (to compare the main precipitates which appeared on the samples after the batch tests). The binding energy of the XPS lines was normalized to the binding energy of $\mathrm{C} 1 \mathrm{~s}=$ $285 \mathrm{eV}$. Lines were standardized to be of the same height.

- Determination of the specific surface area of the iron samples before and after the batch tests. The 
Table 1 Physicochemical parameters and concentrations of chemicals in solutions used in the batch tests for the initial $\mathrm{pH}=4.5,7.0$, and 9.5

\begin{tabular}{|c|c|c|c|c|c|c|c|c|}
\hline Stage of the batch tests & $\mathrm{pH}$ & Cond., uS/cm & ORP, mV & $\mathrm{DO}, \mathrm{mg} / \mathrm{dm}^{3}$ & $\mathrm{Zn}, \mathrm{mg} / \mathrm{dm}^{3}$ & $\mathrm{Fe}(\mathrm{II}), \mathrm{mg} / \mathrm{dm}^{3}$ & $\mathrm{Fe}(\mathrm{III}), \mathrm{mg} / \mathrm{dm}^{3}$ & $\mathrm{SO}_{4}{ }^{2-}, \mathrm{mg} / \mathrm{dm}^{3}$ \\
\hline \multicolumn{9}{|l|}{ Initial $\mathrm{pH}=4.5$} \\
\hline Initial values & 4.53 & 137.8 & 252 & 6.1 & 5.57 & $\mathrm{BDL}$ & BDL & 10.2 \\
\hline $\begin{array}{l}\text { Values after the first } \\
\text { batch tests }\end{array}$ & 5.27 & 132.4 & 155 & 5.0 & 2.10 & 0.26 & 3.22 & 9.4 \\
\hline $\begin{array}{l}\text { Values after the second } \\
\text { batch tests }\end{array}$ & 6.83 & 24.5 & 124 & 5.2 & 0.03 & 0.15 & 0.48 & 1.3 \\
\hline \multicolumn{9}{|l|}{ Initial $\mathrm{pH}=7.0$} \\
\hline Initial values & 7.02 & 110.1 & 186 & 5.8 & 7.06 & $\mathrm{BDL}$ & BDL & 10.2 \\
\hline $\begin{array}{l}\text { Values after the first } \\
\text { batch tests }\end{array}$ & 6.31 & 115.4 & 128 & 5.2 & 1.93 & 0.10 & 1.04 & 9.9 \\
\hline $\begin{array}{l}\text { Values after the second } \\
\text { batch tests }\end{array}$ & 6.95 & 17.8 & 121 & 5.0 & 0.04 & 0.06 & 0.31 & 0.6 \\
\hline \multicolumn{9}{|l|}{ Initial $\mathrm{pH}=9.5$} \\
\hline Initial values & 9.48 & 98.4 & 146 & 6.2 & 6.12 & BDL & BDL & 9.3 \\
\hline $\begin{array}{l}\text { Values after the first } \\
\text { batch tests }\end{array}$ & 6.85 & 104.7 & 138 & 5.5 & 0.17 & 0.04 & 0.10 & 9.1 \\
\hline $\begin{array}{l}\text { Values after the second } \\
\text { batch tests }\end{array}$ & 7.08 & 11.6 & 120 & 5.2 & 0.04 & 0.02 & 0.08 & $\mathrm{BDL}$ \\
\hline
\end{tabular}

$B D L$ below detection limit

measurements of multi-point BET surface area were carried out with the use of Micromeritics Gemini 2360 Surface Area Analyzer. The method utilized a flowing gas technique in which the gas used in the analysis (nitrogen) was introduced into a tube containing the iron sample and into a balance tube at the same time. The principle of measurement consisted in the adsorption of nitrogen on the surface of the sample at a constant temperature of liquid nitrogen (77-78 K). An identical internal volume and ambient temperature of both tubes was maintained. The only difference was the pressure of the sample in the sample tube. The measurement range of the analyzer: specific surface from $0.01 \mathrm{~m}^{2} / \mathrm{g}$. In order to remove impurities and moisture, the samples were dried at $383 \mathrm{~K}$ before the measurements.

- Determination of the affinity of zinc in ionic form with shells coating the iron sample by measuring the $\mathrm{pH}$ at the point of zero charge $\left(\mathrm{pH}_{\mathrm{PZC}}\right)$. The point of zero charge was obtained using batch equilibrium method. This parameter describes the condition $(\mathrm{pH}$ value) in which the electrical charge on the surface of ZVI is zero. The testing procedure was as follows: iron samples obtained from the batch tests (only from the first batch tests) were immersed in demineralised water for ca. $120 \mathrm{~s}$ and then shaken (separately) in plastic tubes for $24 \mathrm{~h}$ with the following: (1) $58 \mathrm{~cm}^{3}$ of $0.01 \mathrm{M} \mathrm{KNO}_{3}$ solution and (2)
$58 \mathrm{~cm}^{3}$ of $0.01 \mathrm{M} \mathrm{KNO}_{3}$ and $10^{-5} \mathrm{M} \mathrm{Zn}$ (II) solution, at different initial $\mathrm{pH}$ values. A suitable amount of $\mathrm{Zn}\left(\mathrm{NO}_{3}\right)_{2}$ was added to the solution to achieve a proper concentration of $\mathrm{Zn}$ (II). The applied sequence of shaking was similar to the previous ones (performed with a programmable MULTI BIO RS24 BIOSAN rotator). The initial $\mathrm{pH}$ levels of the solutions were adjusted by slow titration with ultrapure potassium hydroxide solution $(0.1 \mathrm{M})$ or with ultra-pure nitric acid solution $(0.1 \mathrm{M})$ while keeping the ionic strength constant. The amount of $\mathrm{H}^{+}$or $\mathrm{OH}^{-}$ions adsorbed by iron samples was calculated from the difference between the initial and the final concentrations of $\mathrm{H}^{+}$or $\mathrm{OH}^{-}$ions (Babić et al. 1999). The $\mathrm{pH}$ was measured with the use of Knick PORTAMESS 913 meter and the SenTix 41 electrode (Suponik 2015b, in press).

In order to assess the capability of metals to be released from the precipitates found on the surface of iron samples to demineralised water and to identify the products formed on the surface of the samples after this process, tests using a programmable rotator were carried out for a second time, in a manner similar to the one described before. The only difference was that the iron samples used for removing metals from solutions (after finishing the first batch tests) were inserted into $58 \mathrm{~cm}^{3}$ of demineralised water (DW) poured into plastic tubes. 
The samples in the second batch tests were shaken in the same way as in the case of the first batch tests. The study conducted after the second test was similar, except for the fact that the $\mathrm{pH}_{\mathrm{pzc}}$ measurements were omitted.

\section{Results and Discussion}

\subsection{Study of Water}

As presented in Table 1, the concentrations of zinc in water measured after the first tests decreased in a more rapid manner in case of higher $\mathrm{pH}$ levels of solutions. This observation was also made in the papers by Kishimoto et al. (2011), Rangsivek and Jekel (2005), and Suponik and Blanko (2014). What is noteworthy here is the fact that after the second batch tests, the zinc from the iron sample was not released to demineralised water. The compounds formed on iron in the first tests were fixed. They were not dependent on previous $\mathrm{pH}$ values. The final $\mathrm{pH}$ levels after the second tests were similar in case of all iron samples and amounted approximately to 7. The $\mathrm{pH}$ of DW amounted to 6.8. After the first tests, also, this parameter had the tendency to approach the value of 7 . The parameter increased for low values and decreased for higher ones.

Kishimoto et al. (2011) studied the desorption of zinc from ZVI using sulphuric acid and citric acid solutions. During the backwashing, they observed rapid desorption of zinc when the citric acid solution was used, whereas no desorption was observed when the sulphuric acid was applied. Their conclusion was that the zinc adsorption layer on ZVI was stable in diluted sulphuric acid and became unstable in a reducing agent such as citric acid. This conclusion is consistent with the results obtained in studies using demineralised water.

As the previous work indicates (Suponik 2015a), the lower were the values of $\mathrm{pH}$ in the tests, the higher were the initial values of ORP in the water and the faster was the decrease of this potential after the first batch tests. The ORP of pure DW amounted to $159 \mathrm{mV}$, while in the case of water after the second batch tests, the value reached $120 \mathrm{mV}$. A slight decrease in oxygen concentration may also be noticed after both of the batch tests, which indicates that the course of redox reactions involves oxygen. The initial concentration of oxygen in DW amounted to $6.4 \mathrm{mg} / \mathrm{dm}^{3}$.

The oxidation of $\mathrm{Fe}(0)$ proceeds faster in low $\mathrm{pH}$ (Kowal and Świderska-Bróż 1996; Kishimoto et al.
2011), which is evidenced by the fact that more ions of $\mathrm{Fe}(\mathrm{II})$ iron appeared after the first batch tests in water characterized by a lower initial value of $\mathrm{pH}$. This occurred mostly due to processes described by reactions 1 and 2. A similar correlation was observed in case of the second batch tests, though the concentrations of Fe(II) were lower. This was probably caused by the thin shells which covered the ZVI.

$2 \mathrm{Fe}^{0}+\mathrm{O}_{2}+2 \mathrm{H}_{2} \mathrm{O}^{2} \rightarrow 2 \mathrm{Fe}^{2+}+4 \mathrm{OH}^{-}$

$\mathrm{Fe}^{0}+2 \mathrm{H}_{2} \mathrm{O} \rightarrow \mathrm{Fe}^{2+}+\mathrm{H}_{2}+2 \mathrm{OH}^{-}$

In the presence of dissolved oxygen in water, however, $\mathrm{Fe}(\mathrm{II})$ is oxidized to $\mathrm{Fe}(\mathrm{III})$, which then may produce either $\mathrm{FeOOH}, \mathrm{Fe}(\mathrm{OH})_{3}, \mathrm{Fe}_{2} \mathrm{O}_{3}$, or $\mathrm{Fe}_{3} \mathrm{O}_{4}$ together with $\mathrm{Fe}(\mathrm{II})$ - each in solid form.

$2 \mathrm{Fe}^{2+}+{ }^{1} /{ }_{2} \mathrm{O}_{2}+2 \mathrm{H}^{+} \rightarrow 2 \mathrm{Fe}^{3+}+\mathrm{H}_{2} \mathrm{O}$

Due to the presence of oxygen in the solutions (Table 1), the concentrations of Fe(III) in almost all samples were several times higher than the concentrations of $\mathrm{Fe}(\mathrm{II})$. As it was reported by Kishimoto et al. (2011) and Rangsivek and Jekel (2005), zinc removal by ZVI was enhanced by the presence of dissolved oxygen.

In accordance with the results presented in Table 1, the sulfates in the first batch tests have been removed from the water to a very small extent. Thus, the sulfates were probably not present on the iron sample in the second tests. The release of the sulfates to the water in these tests was very low-especially at higher $\mathrm{pH}$ values.

\subsection{XRD}

Upon visual inspection, the surfaces of the iron samples applied in the first and second tests were covered with gray and yellow-brown precipitates. The amount of yellowbrown deposits seemed to be higher for lower initial $\mathrm{pH}$ values of the solutions. In case of the samples immersed in the solutions of $\mathrm{pH}$ amounting to 9.5, spots of metallic iron not covered by precipitates were visible. The amount of gray precipitates was similar in all the samples.

Figure 1 presents the diffraction of X-rays on iron samples before and after the first and second batch tests. Based on Fig. 1a, it may be claimed that iron was found on the surface of iron samples assessed before the batch tests (as it was expected). The network parameters of 
pure iron are similar (very close) to the parameters of many alloys in which iron is the main component.

Pure iron was also present in samples immersed in solutions characterized by higher initial $\mathrm{pH}$ levels, especially at $\mathrm{pH}=9.5$ (in Fig. $1 \mathrm{~b}, \mathrm{c}$, the theta angle for $\mathrm{Fe}(0)$ amounts to $44.6^{\circ}, 65.0^{\circ}$, and $\left.82.3^{\circ}\right)$. In both the first and the second batch tests for the initial solutions with the $\mathrm{pH}=9.5$, the samples exhibited many spots not covered by precipitates.

On the contrary, lepidocrocite $\gamma-\mathrm{FeO}(\mathrm{OH})$ was identified mainly in case of lower $\mathrm{pH}$ values, especially when the $\mathrm{pH}$ of the solutions was 4.5. According to the XRD graphs plotted for the first and second tests, the theta angle in Fig. 1b, c for $\gamma-\mathrm{FeO}(\mathrm{OH})$ amounts to $14.1^{\circ}, 27.0^{\circ}, 36.3^{\circ}, 38.1^{\circ}$, and $46.8^{\circ} \cdot \gamma-\mathrm{FeO}(\mathrm{OH})$ may correspond to the yellow-brown precipitates on the samples, occurring mainly in lower $\mathrm{pH}$ of the solutions that were used. Lepidocrocite is a common phase often forming as a result of iron corrosion process in the presence of dissolved oxygen (Kamolpornwijit et al. 2004). $\gamma-\mathrm{FeO}(\mathrm{OH})$ was also found on the surface of ZVI after the removal of copper and zinc ions from water (Rangsivek and Jekel 2005). The presence of lepidocrocite indicates that the adsorption of zinc may have occurred as an additional process resulting from the uptake of this metal.

According to the XRD graphs (Fig. 1b, c) obtained after the first and second batch tests, zinc was present in the $\mathrm{Zn}_{x} \mathrm{Fe}_{3-x} \mathrm{O}_{4}$ compound (where $x \leq 1$ ). Diffraction lines obtained from the XRD tests correspond to the compounds, which can be expressed as $\mathrm{Zn}_{x} \mathrm{Fe}_{3-x} \mathrm{O}_{4}$, because the diffraction lines of compounds such as $\mathrm{Zn}^{2+} \mathrm{Fe}^{3+}{ }_{2} \mathrm{O}_{4}, \mathrm{Zn}^{2+}{ }_{0.35} \mathrm{Fe}^{2+}{ }_{0.65} \mathrm{Fe}^{3+}{ }_{2} \mathrm{O}_{4}$, and $\mathrm{Zn}^{2+}{ }_{0.4} \mathrm{Fe}^{2+}{ }_{0.6} \mathrm{Fe}^{3+}{ }_{2} \mathrm{O}_{4}$ are very similar. Theta angles for $\mathrm{ZnFe}_{2} \mathrm{O}_{4}$ are $30.0^{\circ}, 35.4^{\circ}, 43.0^{\circ}, 53.2^{\circ}, 56.8^{\circ}$, and $62.4^{\circ}$. It should be added here that the same pattern was exhibited by all the applied samples, irrespective of the initial $\mathrm{pH}$ of the solutions. $\mathrm{Zn}_{x} \mathrm{Fe}_{3-x} \mathrm{O}_{4}$ may correspond to the gray-colored precipitates.

\subsection{XPS}

Table 2 presents the atomic concentrations of the elements on the iron samples before the study and after the first and second batch tests. Each assessed sample contained carbon and oxygen. It is possible that the

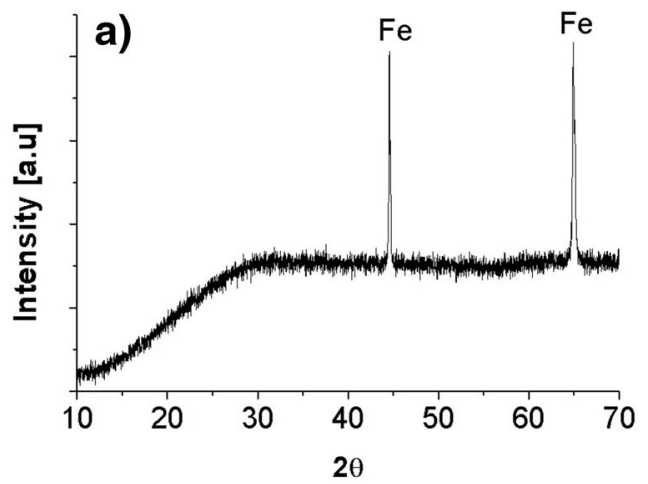

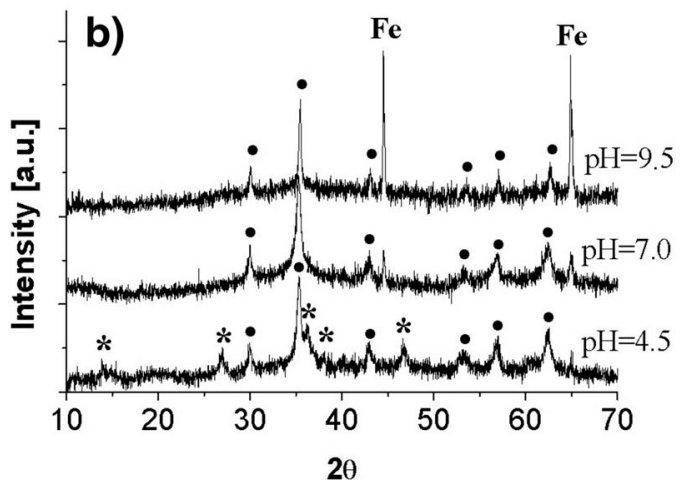

Fig. 1 XRD graphs of iron samples: a before the batch tests; $\mathbf{b}$ after the first batch tests for the initial $\mathrm{pH}$ of the solution amounting to 4.5, 7.0, and 9.5; and $\mathbf{c}$ after the second batch tests for the initial $\mathrm{pH}$

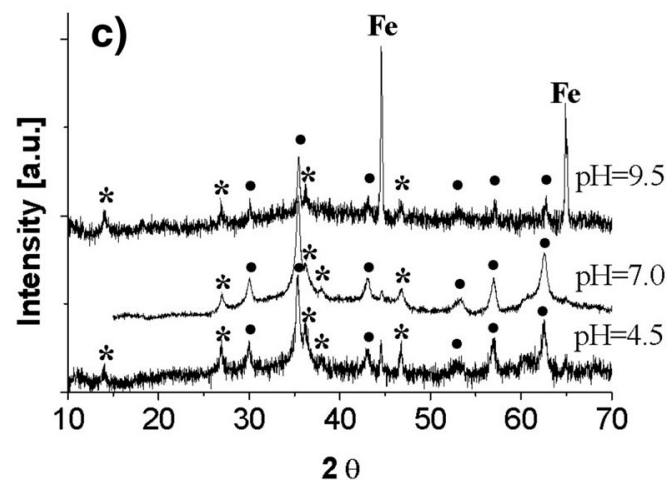

of the solution amounting to 4.5, 7.0, and 9.5. $\mathrm{Fe}-$ Iron in metallic form; ${ }^{*}-\gamma-\mathrm{FeO}(\mathrm{OH}) ; \bullet-\mathrm{Zn}_{\mathrm{x}} \mathrm{Fe}_{3-\mathrm{x}} \mathrm{O}_{4}$ 
oxygen was contained in precipitates in the form of metal oxides and metal hydroxides, while carbon and oxygen in compounds in which the following bonds occur (in very small quantities): $-\mathrm{C}-\mathrm{O}-$ and $-\mathrm{C}=\mathrm{O}$ (binding energy: $\mathrm{C} 1 \mathrm{~s}=$ from 286.51 to $288.64 \mathrm{eV}$, see Fig. 2). The main contribution to the $\mathrm{C} 1 \mathrm{~s}$ line is constituted by hydrocarbons deposited on the surface. This always occurs when a sample is stored in atmospheric conditions. The binding energy of the $\mathrm{C} 1 \mathrm{~s}$ line resulting from the presence of hydrocarbons amounts to $285.0 \mathrm{eV}$.

The oxygen present in the compounds on the surface of the iron samples originated from solutions used in the analysis in the first and second batch tests. The presence of carbon and remaining amounts of oxygen has been explained by the contamination of the samples (by atmospheric air and other factors) during their transport for the measurements. For that reason, the atomic concentrations of oxygen and carbon presented in Table 2 have not been taken into consideration in further analysis.

The results of the tests presented in Table 2 have also shown that zinc and iron formed compounds on the surface of all the samples used in the first and second batch tests. Although the assessments concerned a small area of the samples, it can be concluded that the zinc concentration on iron samples was lower in case of samples introduced to the solution with $\mathrm{pH}=4.5$. This is consistent with the observation that in lower $\mathrm{pH}$ levels of solutions, the removal of zinc proceeded in a less effective manner. On the surface of samples immersed in the solution at $\mathrm{pH}=9.5$, no sulfur was observed based on the results of the XPS. This confirms the previous observation that sulfur is not removed from water at higher $\mathrm{pH}$ values.

The lower concentrations of zinc on the iron samples after the second batch tests as compared to the first tests results (see Table 2) may indicate that this element is released to demineralised water to a small extent. In the opinion of the authors, however, the decrease in the zinc concentration after the second test for the initial $\mathrm{pH}$ of 7 was too big. Most likely, the analysis after the first and the second tests did not include the same locations.

At the same time, while discussing the results of water analysis, it was found that zinc was not released to water after the second batch tests. No indication of zinc in the water may result from the fact that the samples of water were not digested before the measurement in a spectrophotometer. Zinc in the form of other 

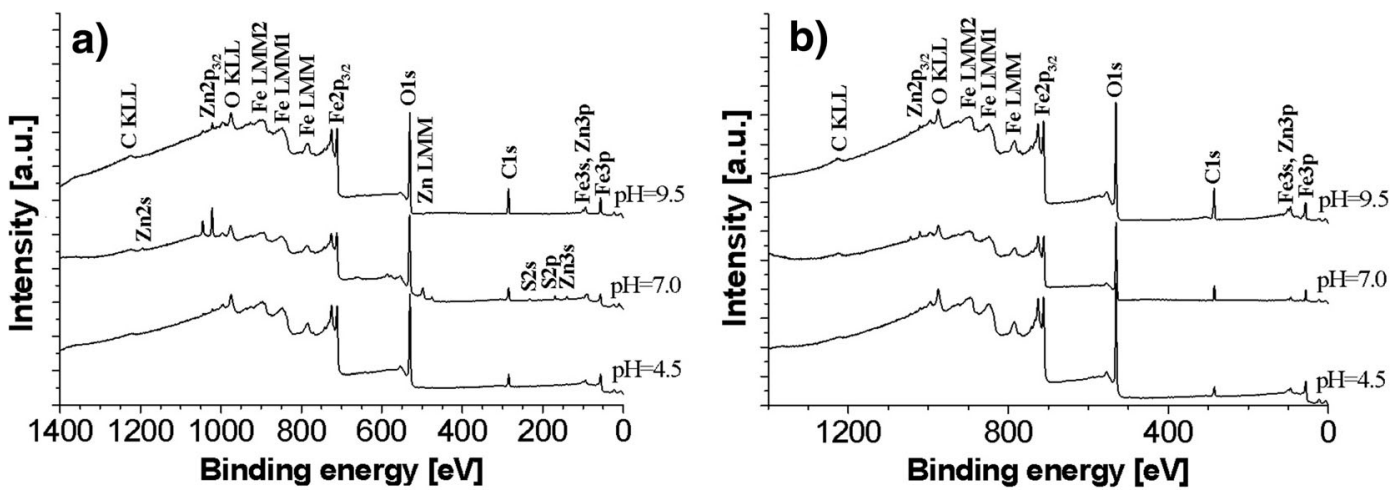

Fig. 2 XPS graphs of the iron samples: $\mathbf{a}$ after the first batch tests for the initial $\mathrm{pH}$ of the solution amounting to 4.5, 7.0, and 9.5 and $\mathbf{b}$ after the second batch tests for the initial $\mathrm{pH}$ of the solution amounting to 4.5, 7.0, and 9.5

compounds may be transferred to water. In a very a small extent, zinc may also be released into the DW.

HRES spectrums of O1s obtained from the XPS consist of two peaks with similar binding energy for all the analyzed samples. The peaks were as follows: $530.1 \pm 0.2$ and $531.6 \pm 0.3 \mathrm{eV}$. They correspond to the metal oxides and metal hydroxides, respectively. The peak at $530.1 \pm 0.2 \mathrm{eV}$, which was a result of a metaloxygen bond, may correspond to many compounds such as the following: $\gamma-\mathrm{Fe}_{2} \mathrm{O}_{3}(529.8 \mathrm{eV}), \mathrm{Fe}_{3} \mathrm{O}_{4}$ (530.0 eV), $\mathrm{FeO}(529.8 \mathrm{eV}), \alpha-\mathrm{FeOOH}(530.1 \mathrm{eV})$, or even to $\mathrm{ZnO}(530.3 \mathrm{eV})$, while the peak at $531.6 \pm$ $0.3 \mathrm{eV}$ corresponds to $\gamma-\mathrm{FeOOH}(531.4 \pm 0.2 \mathrm{eV})$. In case of the first peak, it was difficult to decide which compound corresponded to the binding energy of $530.1 \mathrm{eV}$. Taking into account the results from the diffractometer, however, it may be established that it corresponded either to $\mathrm{Fe}_{3} \mathrm{O}_{4}$, in which the iron atoms have been replaced by zinc atoms or pure magnetite. It should be added that in case of the solutions with the initial $\mathrm{pH}$ of 7.0 and $9.5, \gamma$-FeOOH was also formed, but in smaller quantities, because the photoelectric lines were weak. In addition, X-ray diffractograms provided no evidence for the presence of lepidocrocite in the crystalline form (Fig. 1b).

Furthermore, in the Fe2p spectra for all the samples, the binding energy amounted to $711.3 \pm 0.3 \mathrm{eV}$. This value confirms the presence of $\gamma-\mathrm{FeOOH}$ on the surface of the samples (Fe2p $711.3 \mathrm{eV}-\gamma$-FeOOH).

In case of the iron samples immersed in solutions with the initial $\mathrm{pH}$ values of 4.5, 7.0, and 9.5, the $\mathrm{Zn} 2 \mathrm{p} 3$ / 2 emission line in the registered spectra appeared at the binding energy of $1021.5 \pm 0.4 \mathrm{eV}$. This value corresponds to the $\mathrm{ZnFe}_{2} \mathrm{O}_{4}$ compound. The binding energy of this compound amounts to $1021.4 \mathrm{eV}$. This value has confirmed, according to the data from the $\mathrm{XRD}$ tests, the formation of compounds such as $\mathrm{ZnFe}_{2} \mathrm{O}_{4}$.

As provided by Furukawa et al. (2002), Roh et al. (2000), and Rangsivek and Jekel (2005), the secondary minerals which typically form on the surface of ZVI as a result of purification of water contaminated by metals in ionic forms are as follows: $\gamma-\mathrm{FeOOH}, \mathrm{Fe}_{3} \mathrm{O}_{4}, \mathrm{Fe}_{2} \mathrm{O}_{3}, \alpha$ $\mathrm{FeOOH}, \mathrm{CaCO}_{3}, \mathrm{Fe}(\mathrm{OH})_{2}, \mathrm{Fe}_{2} \mathrm{O}_{3} \cdot 0.5 \mathrm{H}_{2} \mathrm{O}, \mathrm{FeCO}_{3}$, $\mathrm{FeS}_{2}, \mathrm{Fe}_{3} \mathrm{~S}_{4}$, mackinawite $\left((\mathrm{FeNi})_{1+x} \mathrm{~S}\right.$, where $x=0$ to $0.11)$, and green rust $\left(\left[\mathrm{Fe}_{1-x}{ }^{2+} \mathrm{Fe}_{x}{ }^{3+}(\mathrm{OH})_{2}\right]^{x+}\left[x / n \mathrm{~A}^{n-}\right.\right.$. $\left.\mathrm{mH}_{2} \mathrm{O}\right]^{x-}$, where $x$ is the $\mathrm{Fe}^{3+} / \mathrm{Fe}_{\text {tot }}$ ratio), which is usually formed under neutral $\mathrm{pH}$ conditions. Although according to Wilkin and McNeil (2003), green rust is a primary corrosion product formed on ZVI in sulfate-rich solutions, it has not been observed (by visual inspection) on the surface of the iron sample and there has been no evidence of it in the presented results. This is probably due to the "pure" conditions of purification. As provided by Cornell and Schwertmann (1996), green rust is stable only at low grades of oxide reduction and its oxidation usually leads to the formation of $\mathrm{Fe}_{2} \mathrm{O}_{3}$ or $\gamma$ $\mathrm{FeOOH}$. Roh et al. (2000) also reported that green rust is an intermediate stage and is finally transformed into $\alpha$ - $\mathrm{FeOOH}, \gamma$-FeOOH, $\mathrm{Fe}_{3} \mathrm{O}_{4}$, and $\mathrm{Fe}_{2} \mathrm{O}_{3}$.

The formation of magnetite (in pure form) was investigated by Grosvenor et al. (2004), Kamolpornwijit et al. (2004), and Karabelli et al. (2008). The latter has noted (on the basis of XRD analyses) a slow development of iron oxides, primarily in the forms of $\mathrm{Fe}_{3} \mathrm{O}_{4}$ and $\gamma-\mathrm{Fe}_{2} \mathrm{O}_{3}$. Kishimoto et al. (2011) reported that the iron hydroxide formed in earlier stages was finally oxidized and transformed into iron oxides.

In conclusion, based on the results of the XPS and $\mathrm{XRD}$, the products formed on the surface of ZVI as a result of zinc removal from water were the following: 
(1) magnetite, in which zinc replaces iron creating $\mathrm{Zn}_{\mathrm{x}} \mathrm{Fe}_{3-\mathrm{x}} \mathrm{O}_{4}$ - in acidic, neutral, and alkaline conditions and (2) lepidocrocite, mainly in acidic conditions. After the second batch tests, i.e., after inserting the samples into demineralised water, the same compounds remained on the ZVI.

Ferrous and ferric ions were formed as a result of the reactions 1, 2, and 3, while $\mathrm{Zn}^{2+}{ }_{(x)} \mathrm{Fe}^{2+}{ }_{(1-x)} \mathrm{Fe}^{3+}{ }_{2} \mathrm{O}_{4}$ was formed in accordance with Eq. 4 :

$$
\begin{aligned}
& (1-x) \mathrm{Fe}^{2+}+2 \mathrm{Fe}^{3+}+x \mathrm{Zn}^{2+}+2 \mathrm{H}_{2} \mathrm{O} \\
& +\mathrm{O}_{2} \rightarrow \mathrm{Zn}^{2+}{ }_{(x)} \mathrm{Fe}^{2+}{ }_{(1-x)} \mathrm{Fe}^{3+}{ }_{2} \mathrm{O}_{4}+4 \mathrm{H}^{+}
\end{aligned}
$$

where $x \leq 1$.

\subsection{Specific Surface of Iron Samples}

The values of specific surface areas obtained by means of multi-point BET method for the iron samples immersed in the zinc solutions with the $\mathrm{pH}$ values of $4.5,7.0$, and 9.5 (after the first batch tests) were $0.2704,0.3324$, and $0.2741 \mathrm{~m}^{2} / \mathrm{g}$, respectively, while these same parameters for the samples immersed in DW (after the second batch tests) equalled to $0.2482,0.3521$, and $0.2908 \mathrm{~m}^{2} / \mathrm{g}$. In case of the iron samples before the batch tests, the parameter amounted to $0.0302 \mathrm{~m}^{2} / \mathrm{g}$, which means that large amounts of chemical compounds have formed on the surface of the iron samples after the tests, especially at the initial $\mathrm{pH}=7.0$. It may be stated that after inserting the samples into DW, the surface area did not change. Based on these results, either the
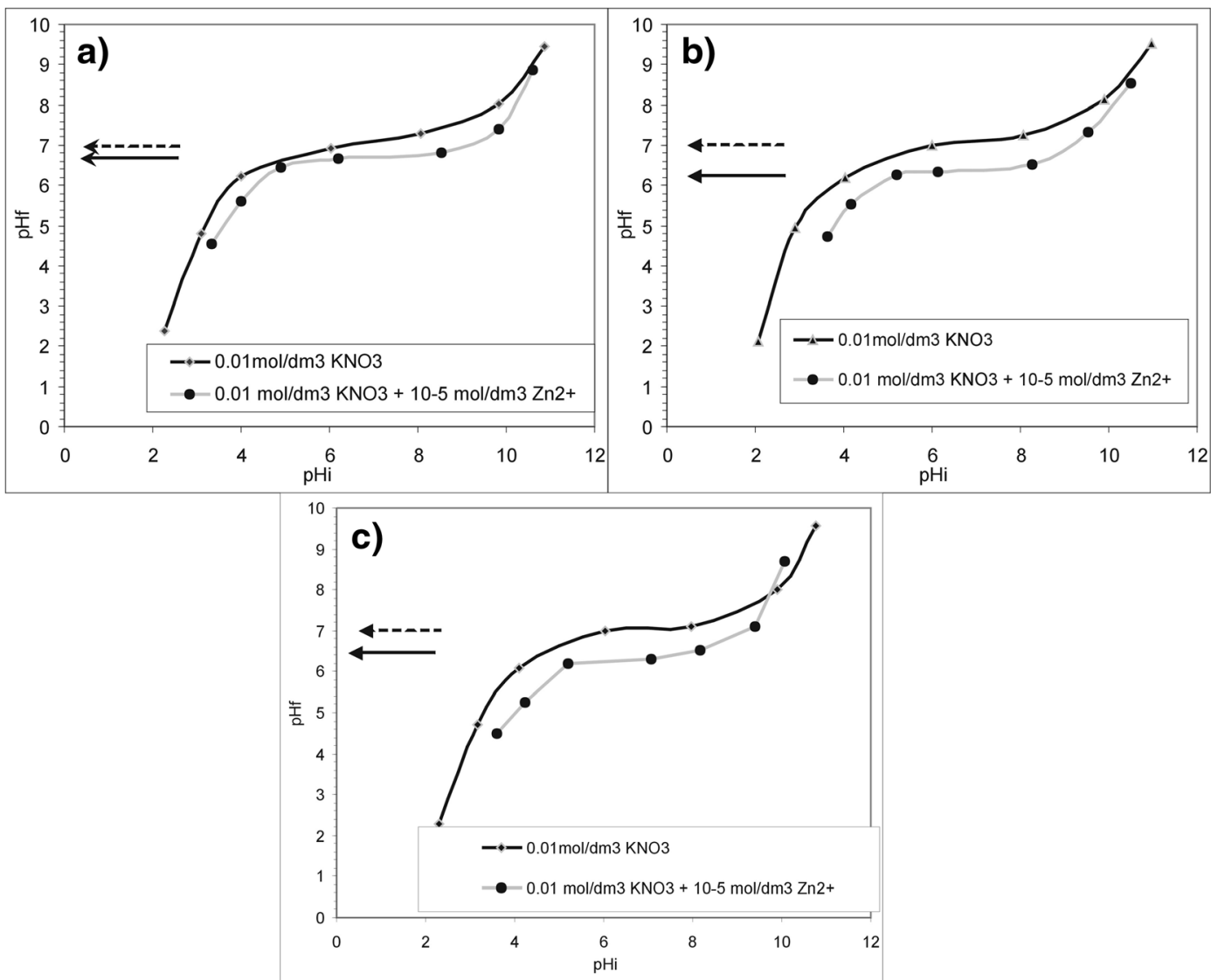

Fig. 3 The final value of $\mathrm{pH}\left(\mathrm{pH}_{\mathrm{f}}\right)$ vs. the initial value of $\mathrm{pH}\left(\mathrm{pH}_{\mathrm{i}}\right)$ for the iron samples immersed (separately) in two solutions: $0.01 \mathrm{M}$ $\mathrm{KNO}_{3}$ and $0.01 \mathrm{M} \mathrm{KNO}_{3}+10^{-5} \mathrm{M} \mathrm{Zn(II).} \mathrm{Three} \mathrm{samples} \mathrm{have} \mathrm{been}$ used in each solution: a the one that was shaken in a solution with the initial $\mathrm{pH}=4.5$, $\mathbf{b}$ the one that was shaken in a solution with the initial $\mathrm{pH}=7.0$, and $\mathbf{c}$ the one that was shaken in a solution with the initial $\mathrm{pH}=9.5$ 
substances were not released into the water, or new compounds have been created on the surface of the samples.

\section{$3.5 \mathrm{pH}_{\mathrm{pzc}}$}

Figure 3 presents the results of the tests conducted for the determination of $\mathrm{pH}_{\mathrm{pzc}}$. The $\mathrm{pH}$ at the point of zero charge, determined by batch equilibrium method for the three iron samples (that have been used in the zinc solution at the initial $\mathrm{pH}=4.5,7.0$, and 9.5) which were shaken in $0.01 \mathrm{M} \mathrm{KNO}_{3}$ solutions, amounted to $7 \mathrm{pH}_{\mathrm{f}}$ level at which a common plateau is reached, see the dashed arrows in Fig. 3). This leads to the conclusion that $\mathrm{pH}_{\mathrm{pzc}}$ is independent from the initial $\mathrm{pH}$ of zinc solutions.

In the presence of zinc ions in solutions, $\mathrm{pH}_{\mathrm{pzc}}$ decreases to the value of ca. 6.7, 6.3, and $6.4 \mathrm{pH}_{\mathrm{f}}$ level at which a common plateau is reached, see the solid arrows in Fig. 3), respectively, for initial $\mathrm{pH}$ values of the solutions amounting to 4.5, 7.0, and 9.5. The decrease in $\mathrm{pH}_{\mathrm{pzc}}$ is due to the specific adsorption of counter ions. The values of point of zero charge for iron oxides (hydroxide) are as follows: 7.8 for lepidocrocite $\gamma$-FeOOH, from 3.8 to 8.2 for magnetite, from 6.1 to 7.5 for maghemite $\gamma-\mathrm{Fe}_{2} \mathrm{O}_{3}$, from 5.5 to 9.3 for hematite $\alpha-\mathrm{Fe}_{2} \mathrm{O}_{3}$, from 6.2 to 9.6 for goethite $\alpha-\mathrm{FeOOH}$, and from 6.0 to 6.5 for iron(II) hydroxide (Kosmulski 2011).

Based on the above, it may be stated that the sorption of $\mathrm{Zn}$ (II) on the surface of samples is not possible for the solution with the initial $\mathrm{pH}$ of 4.5 , in case of which the final $\mathrm{pH}$ was 5.27 (see Table 1), while it may occur in case of the solutions with the initial $\mathrm{pH}$ of 7.0 and 9.5 , for which the final $\mathrm{pH}$ was 6.31 and 6.85 , respectively (see Table 1). The shells coating the iron samples following the tests exhibited nearly equal the amounts of negative and positive charges, as the $\mathrm{pH}$ of the solutions (6.31 and 6.85) was close to the pzc of the compounds which have formed on the surface of the iron samples. Since both the charges exist in the shells coating the samples at this $\mathrm{pH}$, the sorption of $\mathrm{Zn}$ (II), as well as the negatively charged ions which were present in the solution, may occur at the surface of the samples.

In the research described in the papers by Kishimoto et al. (2011) and Rangsivek and Jekel (2005), the zinc removal process was also enhanced at higher $\mathrm{pH}$ values.

\section{Conclusions}

ZVI has the capacity to remove zinc from water in a wide range of $\mathrm{pH}$ values. The concentrations of zinc in water decreased much faster in higher $\mathrm{pH}$ levels of the solutions. At the same time, zinc was not released to demineralised water from the precipitates located on the ZVI (or was released to a small extent), as DW is not a reducing agent. The results of the XPS indicated, however, that some amount of zinc can be released into demineralised water. The specific surface of iron samples, in turn, did not change after inserting the samples into DW. In this case, no conclusion can be drawn. It can only be stated that zinc may be released into the DW to a very limited extent-if at all.

The products formed on the surface of the ZVI as a result of zinc removal from water were dependent on the initial $\mathrm{pH}$ values of the solutions. Under acidic conditions $\gamma-\mathrm{FeO}(\mathrm{OH})$ and $\mathrm{Zn}_{\mathrm{x}} \mathrm{Fe}_{3-x} \mathrm{O}_{4}$ (where $x \leq 1$ ) were the main precipitates, while under alkaline conditions, the iron surface was covered with $\mathrm{Zn}_{x} \mathrm{Fe}_{3-x} \mathrm{O}_{4}$ and to a lesser extent with $\gamma-\mathrm{FeO}(\mathrm{OH})$. For lower initial values of $\mathrm{pH}$, the presence of sulfates on the surface of the samples has also been identified. Similar observations to the ones described above were made for the second batch tests, in which the ZVI samples were submerged in demineralised water. To summarize, $\mathrm{Zn}_{x} \mathrm{Fe}_{3-x} \mathrm{O}_{4}$ was the main compound generated as a result of the removal of zinc in ionic form from water in a wide range of $\mathrm{pH}$ values.

The adsorption of $\mathrm{Zn}$ (II) on the surface of precipitates which have formed on the ZVI may occur as an additional process in neutral and high $\mathrm{pH}$ of solutions, since the $\mathrm{pH}$ was approximately $6.3-6.4$ at point of zero charge for shells coating zero-valent iron. The final $\mathrm{pH}$ of these solutions reached the values of 6.31 and 6.85 .

Open Access This article is distributed under the terms of the Creative Commons Attribution 4.0 International License (http:// creativecommons.org/licenses/by/4.0/), which permits unrestricted use, distribution, and reproduction in any medium, provided you give appropriate credit to the original author(s) and the source, provide a link to the Creative Commons license, and indicate if changes were made.

\section{References}

Babić, B. M., Milonjić, S. K., Polovina, M. J., \& Kaludierović, B. V. (1999). Point of zero charge and intrinsic equilibrium constants of activated carbon cloth. Carbon, 37, 477-481. 
Bruzzoniti, M. C., \& Fiore, S. (2014). Removal of inorganic contaminants from aqueous solutions: evaluation of the remediation efficiency and of the environmental impact of a zero-valent iron substrate. Water, Air, and Soil Pollution, 225(9), 1-14.

Cornell, R. M., \& Schwertmann, U. (1996). The iron oxidesstructure, properties, reactions, occurrence and uses (p. 573). New York: VCH Publishers.

Furukawa, Y., Kim, J. W., Watkins, J., \& Wilkin, R. T. (2002). Formation of ferrihydrite and associated iron corrosion products in permeable reactive barriers of zero-valent iron. Environmental Science and Technology, 36(24), 5469-5475.

Grosvenor, A. P., Kobe, B. A., Biesinger, M. C., \& McIntyre, N. S. (2004). Investigation of multiplet splitting of Fe 2p XPS spectra and bonding in iron compounds. Surface and Interface Analysis, 36, 1564-1574.

Kamolpornwijit, W., Liang, L., Moline, G. R., Hart, T., \& West, O. R. (2004). Identification and quantification of mineral precipitation in $\mathrm{Fe} 0$ filings from a column study. Environmental Science and Technology, 38(21), 5757-5765.

Karabelli, D., Uzum, C., Shahwan, T., Eroglu, A. E., Scott, T. B., Hallam, K. R., \& Lieberwirth, I. (2008). Batch removal of aqueous $\mathrm{Cu}^{2+}$ ions using nanoparticles of zero-valent iron: a study of the capacity and mechanisms of uptake. Industrial and Engineering Chemistry Research, 47, 4758-4764.

Kishimoto, N., Iwano, S., \& Narazaki, Y. (2011). Mechanistic consideration of zinc removal by zero-valent iron. Water, Air, and Soil Pollution, 221(1-4), 183-189.

Kosmulski, M. (2011). The pH-dependent surface charging and points of zero charge: V. Update. Journal of Colloid and Interface Science, 35(1), 1-15.

Kowal, L. A., Świderska-Bróż, M., \& Swiderska-Bróż, M. (1996). Oczyszczanie wody. Warszawa-Wrocław: PWN.

Li, X. Q., \& Zhang, W. X. (2007). Sequestration of metal cations with zerovalent iron nanoparticles: a study with high resolution X-ray photoelectron spectroscopy (HRXPS). Journal of Physical Chemistry, 111(19), 6939-6946.
Morrison, S. J., Metzler, D. R., \& Dwyer, B. P. (2002). Removal of As, Mn, Mo, Se, U, V and Zn from groundwater by zerovalent iron in a passive treatment cell: reaction progress modeling. Journal of Contaminant Hydrology, 56(1), 99116.

Oh, B., Lee, J., \& Yoon, J. (2007). Removal of contaminants in leachate from landfill by waste steel scrap and converter slag. Environmental Geochemistry and Health, 29(4), 331-336.

Rangsivek, R., \& Jekel, M. R. (2005). Removal of dissolved metals by zero-valent iron (ZVI): kinetics, equilibria, processes and implications for stormwater runoff treatment. Water Research, 39, 4153-4163.

Roh, Y., Lee, S. Y., \& Elless, M. P. (2000). Characterization of corrosion products in the permeable reactive barriers. Environmental Geology, 40, 184-194.

Ronald, E. (1993). Zinc hazard to fish, wildlife, and invertebrates: a synoptic review. Contaminant hazard reviews. Laurel, Maryland: U.S. Department of the Interior, Fish and Wildlife Service (10).

Suponik, T. (2015a). Zero-valent iron for inorganic contaminants removal from low $\mathrm{pH}$ water. Environment Protection Engineering, 41(1), 15-27.

Suponik, T. (2015b). Study of precipitates formed on the iron reactors following the removal of copper from water. Environment Protection Engineering, in press.

Suponik, T., \& Blanko, M. (2014). Removal of heavy metals from groundwater affected by acid mine drainage. Physicochemical Probl of Miner Process, 50(1), 359-372.

Takeno, N. (2005). Atlas of Eh-pH diagrams; Intercomparison of thermodynamic databases. National Institute of Advanced Industrial Science and Technology, Geological Survey of Japan Open File Report No. 419, 102.

Wilkin, R. T., \& Mcneil, M. S. (2003). Laboratory evaluation of zero-valent iron to treat water impacted by acid mine drainage. Chemosphere, 53, 715-725. 